\title{
Community Reflections on Intergenerational Sexual Relations in Solwezi District
}

\author{
Article by Daniel L. Mpolomoka ${ }^{1}$, Christine Mushibwe ${ }^{2}$, Mbono Dube ${ }^{3}$, Mwewa \\ Musonda $^{4}$, Phyllis Sumbwa ${ }^{5}$, Michael M. Mabenga ${ }^{6}$, Esther Kanduza ${ }^{7}$ \\ ${ }^{1}$ Lecturer, Zambian Open University \\ ${ }^{2}$ Vice Chancellor, University of Africa \\ ${ }^{3} \mathrm{Head}$, Department of Secondary Education, Zambian Open University \\ ${ }^{4}$ Assistant Commissioner of Police, Lusaka, Zambia Police \\ ${ }^{5}$ Resident Lecturer, Department of Adult Education and Extension Studies, University of \\ Zambia \\ ${ }^{6}$ Director, Quality Assurance \& Extension Studies, Zambian Open University \\ ${ }^{7}$ Head, Department of Guidance \& Counselling, Zambian Open University \\ E-mail: mpolomokadaniel@yahoo.com ${ }^{1}$, christine.sankhuleni@hotmail.com ${ }^{2}$, \\ mbonodube@yahoo.com ${ }^{3}$, mwewamusonda@yahoo.com ${ }^{4}$, mabengamm@yahoo.com.sg ${ }^{6}$, \\ kanduzae@yahoo.com ${ }^{7}$
}

\begin{abstract}
This article details occurrences of intergenerational sexual relations in Solwezi District, NorthWestern Province of Zambia. Today, there is an increase in the number of intergenerational sexual relations in the District because of the influx of migrants from other parts of Zambia and world over, who want to take part in mining in the area, as well as engage into business. Using a retrospective research approach, the study targeted all males and females engaged in the vice, sampled by snowballing. Findings of the study were analysed descriptively and thematically. Findings reveal the following:

1.That poverty is the major drive towards intergenerational sexual relations.

2.That though poverty may drive individuals to engage in the vice's other reasons such as peer pressure, pleasure, desire for luxuries, having an edge over others, culture etc. may be the cause for intergenerational sex

3.Despite well-known consequences of engaging in the vice socially sanctioned attitudes and behaviours are linked to cross-generational sex.

4.People's aspirations and expectations may be influenced by the size of the economy such that as the economy keeps growing new needs and desires consistent with the economy may be the drives of behavior.

This study recommends that the people be equipped with necessary tools that will enable them to find alternatives to replace the need to engage in sexual relations with older men and women as a means of survival. Another important recommendation is that mandatory sensitization should be undertaken by investing companies to avert the social backlash that arise in such situations.
\end{abstract}

Keywords: Intergeneration, Sexual Relations, Migrants.

\section{Introduction}

Solwezi is home to one of Zambia's biggest copper mines. It is the capital of the North-Western Province, one of Zambia's poorest provinces. It is a fast growing district as most people are migrating to the District to work in the mines. Solwezi has seen drastic economic growth with the discovery of the copper mines. According to the Solwezi Effect (2018) Solwezi is now home to FQMs Kansanshi Mine producing 260000 tonnes of copper a year. Such an occurrence is seen as a catalyst for economic development. Solwezi town is currently a big busy shantytown growing economically. While The Solwezi Effect contest that mines stimulate local economies and drive growth resulting in the creation of jobs, wealth and disposable income, hidden in all these attractive activities is the 
intergenerational sexual activities taking place among the adolescent girls. The population increase in the district is due to the mining activities.

The article provides the profile of individuals who engage in intergenerational sexual relations in Solwezi District and details the motives for engagement, challenges and benefits. Thereafter, it provides a critical reflection, conclusion and recommendations.

\section{Objective}

The main objective of this study was to describe occurrences of intergenerational sex relations among males and females in the urban areas of Solwezi District.

\section{Statement of the problem}

Solwezi District has become a final destination and dwelling place of choice of many Zambian and foreign migrants. Being a booming mining harbor, second to the Copperbelt, many are moving to that part of the country to take up mining jobs and conduct business. This has made the lifestyles, personal life traits and trends change. There has been a notable increase in intergenerational sexual relations amongst boys and girls, men and women of all ages. Media reports, revelations from various communities and rampant police reports are evident enough of this vice. This prompted the researchers to undertake this study.

\section{Literature review}

The phenomenon of cross generational sex defined as sexual relationships between an adolescent girl and a partner who is older, usually by 10 or more years can be linked to many lifelong consequences. In the case of girls, premature sex can trap them in an adverse poverty and vulnerability cycle as they may become adolescent mothers, may be forced to leave school; are at risk of entering marriage early to preserve the honor of their family and themselves; and, particularly when having sex with older men, are more exposed to contracting sexual diseases, including HIV and AIDS (Kelly et al., 2003, Konde Lule and Morris, 1997; Luke and Kurz, 2002; Nyanzi et al., 2000). Mavhandu-Mudzusi (2014) argues that adolescent girls are vulnerable to exploitation due to poverty. While Mavhandu-Mudzusi agrees with the concept of transactional intergenerational sex, the author contests that young adolescents in poor households are more likely to engage in intergenerational sexual relationships.

Common in cross generational relationships is that the older partner tends to be financially better off. This is used as bet to draw the young adolescent girls desiring financial help. Benje (2017) states that the older as a 'keeper' of the young through material objects. This proposition sits well in the description of these relationships whose basis is "give and take".

In most cases, these cross generational relationships become transactional. However, Bantebya et al., (2014) insist that the nature of cross generational relationships can take the form of transactional and "pull and push" depending upon the setting. They claim that in a rural setting, adolescent girls tend to be pulled and pushed into the vice while in the high-density urban setting, the adolescent girls transact for quick cash or 'luxury' material items and services. The rural setting tends to be characterized by poverty driven desires to a better economic future, protection and stable marriage. The adolescent girls, impoverished and vulnerable will do anything to get into cross generational relationship in an effort to get themselves out of poverty. The relationship emerges as an easy and readily attainable tactic to meet an increasing list of both needs and wants that can range from food, tuition fees to makeup, designer handbags, artificial/human hair and access into exclusive social circles. Such assumption is strongly supported by Leclerc-Madlala (2008). In contrast, the highdensity urban setting is characterized by competitive life styles driven by desperation to earn quick income as an access to "luxury" materials and services and hence will transact in cross generational relationship in "keeping up with the Joneses".

Benge (2017) highlights how the media tend to portray intergenerational relationships as 'unnatural' and 'wrong' due to the age-discrepancy. The age difference in the relationship is not expected and hence the assumption of it being 'unnatural' and 'wrong'. Rubin (1993:11-12) contends that "the lowest of all on the hierarchical system of sexual value are those whose eroticism 
transgresses generational boundaries." The cultural disposition of Zambia, remains a proclivity of many who hold dearly their cultural obligation, hence, may perceive cross generational relationships as a taboo and incestuous because there is crossing of cultural boundaries of acceptable sexualities. However, there has been a steady shift and intergenerational relationship have assumed various definitions. Intergenerational relationships, therefore, remain equivocal making it difficult to frame, structure and implement the child protection policies and interventions as concluded by Bantebya et al., (2014).

It is interesting to note the characteristics of intergenerational relationships, one of which is power. This can be physical, economic or age power. Benge (2017) argues that intergenerational relationships demonstrates imbalance of power. For Benge, power can lie in the hands of the younger partner who is seen as exploiting the older partner. Such an assumption may not apply in the case of Zambia where the older is perceived as exploiting the younger with his wealth to gain sexual favors in turn. Critically, power could lie in the hands of both or the older partner. The older partner can be considered as the 'keeper and spoiler', while the younger can be the 'erogenous sex giver'. Both partners have distinct roles to play and to maintain and sustain the relationship. The roles have to be played well; the young has/must remain sexually attractive and the older keep providing as noted by Leclerc-Madlala (2008). Unfortunately, such an imbalance of power can result into what Bantebya et al., (2014) posit as physical abuse, sexual and exploitation abuse can be the consequences of this relationship and depending upon power in a partner.

A review of the literature on cross generational sex in Sub Saharan Africa uncovered that the motivations behind adolescent girls engaging in sexual relationships with older men were varied and overlapping, with gifts and other financial benefits the major incentive for such relationships (Luke and Kurz, 2002). Motivations for financial rewards tend to be complex, ranging from economic survival to desire for status and possessions.

Across Sub-Saharan Africa, researchers have documented the practice of exchanging sex for money or gifts in relationships. The phenomenon exists beyond the realm of prostitution. While many studies have recognized transactional sex as a consequence of women's poverty and economic dependence on men, literature has increasingly proposed that material exchange for sex is not necessarily linked to urgent food and shelter needs (Wamoyi et al, 2010:1). For example, in Southern Uganda, a study found that half of secondary school girls studied would not have sex for free, no matter their socio-economic status (Nyanzi et al, 2001). Furthermore, in rural Tanzania, intensive participant observation discovered that material exchange for sex was very common, regardless of affluence (Wamoyi et al, 2010:14). In this practice, obligations do not necessarily involve a predetermined payment or gift, but there is a definite motivation to benefit materially from the sexual exchange.

The term "transactional sex" is often used in public health literature as a neatly defined term, but the concept is very complicated and highly contested According to Jewkes et al (2012) transactional sex seems to be open to many interpretations; it is highly dependent on the social, cultural, and personal context of a relationship. The practice lies on a continuum of sexual behavior that exists universally. On one end of the spectrum lies prostitution; on the other end of the spectrum lies the common practice of the exchange of gifts in sexual relationships (Sawers \& Stillwaggon, 2010; Kaufman \& Stavrou, 2004). Leclerc-Madlala (2008:7) argues that "age disparate sex assumes a reciprocal/transactional element which is part of a system of interdependence that is maintained by two interlinked and long-enduring cultural prescriptions."

As a result, the exact definition of transactional sex can be very difficult to ascertain. As wealth accumulates with age, many transactional relationships are also intergenerational. Various literature defines intergenerational relationships as those that exist across an age disparity of 10 or more years (Leclerc Madlala, 2008). An age disparate relationship, on the other hand, refers to a separation of 5 years or more (Leclerc Madlala, 2008:18).

Despite this, young women cannot be viewed as simple victims in the transactional, cross generational relationship. Age disparate relationships are meaningful for both men and women involved; they are perceived as socially, physically, psychologically, economically, and symbolically beneficial by participants (Leclerc Madlala, 2008: 17). 
The consequences of intergenerational sexual relationships are many. These include, early marriage, unwanted sex and children, single motherhood, physical abuse, sexual abuse and exploitation, psycho-emotional trauma and HIV/AIDS (Bantebya et al., 2014). Mavhandu-Mudzusi (2014) identifies intergenerational sex as a key driver of the HIV/AIDS epidemic.

\section{Methodology}

This was purely a qualitative research study, which employed a retrospective research approach. It was easy to fall back on data from similar studies undertaken by NGOs and Government ministries like the Ministry of Community Development and Social Services, Ministry of Health (Education Division), Central Statistics Office, and Ministry of Education.

A total of 30 females, 25 males, 10 Government Heads of Departments (Ministry of Community Development and Social Services; Ministry of Health - Hospital and District Office; Ministry of Education - Education Standards Officers; The Council; The Police; The Church; The Traditional Leadership; Parent Teacher Association representatives; Head Teachers - Primary and Secondary Schools; and Guidance and Counselling Teachers - Primary and Secondary Schools. All the aforementioned were targeted because of their familiarity with the topic under study. In one way of the other, they relate with, interact with and or handle cases of persons who engage in intergenerational sexual relations. They provided valuable information as key informants.

Snowball sampling strategy was employed to select participants. One participant with familiarity of persons under study led to a family member or friend who had similar knowledge and or experiences. Thus, it was easy to interview key informants who actually provided very helpful and valuable information regarding the topic area under study. Information was collected using interviews with key informants. In addition, observations and document review provided helpful information to the study. Descriptive analysis and thematic methods of data analysis were predominantly employed.

\section{Findings and discussion}

\section{Study setting}

The setting influences the nature of the cross-generational sexual relationships adolescents engage in. In rural contexts, impoverished and vulnerable adolescent girls are 'pulled' into sexual relationships with older male partners in the hope of stable marriage, protection and/or a better economic future. Girls are also 'pushed' into cross-generational relationships as a result of their or the family's inability to meet basic needs, violence and maltreatment in the household, lack of awareness of alternatives and lack of recourse to essential services. In addition, environmental conditions in rural areas tend to raise the circumstance that drive the adolescent girls to fall prey of older men seeking casual sex in exchange of money. A good example is long distances in isolated environments which expose girls as easy target for men with cars or money when assistance is sort from older men, generally in exchange for sexual favours.

While poverty is a driver of girls or boys taking part in cross-generational sex, and the negative consequences are well known in both rural and urban contexts, socially sanctioned attitudes and behaviours linked to cross-generational sex, especially that involving men and teenage girls, are not well understood among policymakers and practitioners.

In high-density urban Solwezi settlements, the relationships adolescents engage in have largely taken the form of transactional sex, driven by desperation to earn quick cash for daily survival, but also increasingly as a 'lifestyle choice' fostered by peer pressure to gain easy access to 'luxury' material items and services that would not otherwise be affordable through other income generation options available to adolescents in these contexts. One distinction that is apparent is the different perceptions held by men and women, both young and old: men and boys have a tendency to perceive that girls seek 'luxuries' in cross-generational relationships, whereas girls and women often declare a stronger interest in meeting basic needs.

As the economies of Solwezi District keeps expanding, so too are people's aspirations and expectations. Young women have new needs and desires consistent with the ideals of a modern lifestyle, gender equality and relationships that mimic globalised images of glamour and romance. For many young women, relationships with moneyed older men provide a readily available and socially- 
acceptable way of meeting a growing list of needs and wants, from bread and school fees, to designer handbags and access to elite social circles. Such aspirations in societies where the rich-poor gap is widening and women have limited means to financial independence, coupled with cultural allowances for mixed-age relationships and the intertwining of sexual and economic power, drive.

\section{Economic drivers}

Participants revealed that economic challenges, manifested in acute income and subsistence poverty and ill being in both rural and urban, were critical in pushing adolescent girls and boys into transactional, cross-generational sexual relationships. Economic challenges in Solwezi are typified by low agricultural income and subsistence poverty, characterized by inability to meet basic needs such as food, clothes, decent shelter, health care and school fees for children. Largely based on subsistence agriculture, poverty is attributed largely to chronic cash shortfalls resulting from meagre household incomes, poor agricultural yields and large families comprising numerous dependent young children. In the high-density Solwezi slums (Zambia compound, Kyawama, Kazomba, Wisdom, Chijingejinge, Kimakolwe, Kandemba, Muzabula and Highland), where the economy is more cash-based and where family size is comparatively smaller, poverty is seen as leading to fewer and riskier livelihood choices. In this case, entrenched poverty and hardship are attributed mainly to limited employment opportunities in both the formal and the informal sector.

Some studies such as that conducted by Adogu et al (2004) have linked economic motives to the level of poverty of the adolescent involved: whereas very poor adolescent girls engage in these relationships to meet their basic needs, others who are less poor might do so in order to gain access to what they see as 'luxury goods' or through peer pressure (Hawkins, et al., 2009). For example, poorer girls in rural areas might agree to have sex with an older man in exchange for food, whereas girls in urban areas, with more diverse livelihoods, might enter into these transactional relationships to access items they could not otherwise afford, such as certain clothes or perfume.

The pivotal role of poverty and ill being as drivers of cross generational sexual relationships in the high-density Solwezi slums (Zambia compound, Kyawama, Kazomba, Wisdom, Chijingejinge, Kimakolwe, Kandemba, Muzabula and Highland) is illustrated in the following quotes by research participants:

Inability is mainly about lack of money, and land where to dig (farm). This is where our children's problems originate. If you cannot buy your daughter even a skirt, an old man will offer her one, and entice her into a sexual relationship (Traditional Leadership, Village 2)

'If you are poor and unable to give your daughter what she wants, she will be pushed to the old man, who is enticing her with modern goodies. But if you give her these things she may be contented, and avoid the old man.' (Traditional Leadership, Village 1)

'Because of poverty, the girls look for (taxi drivers, truck drivers, bus drivers, salaried workers) to buy them what us their parents and guardians don't give them. You just notice when they lose respect for you that they are seeing boys and men'. (PTA representative, Male, aged 58; Female aged 51)

'Because of poverty, there is domestic violence which forces girls out of homes; because of poverty the girls look for alternative means of survival'. (Police Officer, Female; Guidance Teacher, Male; Clergy, Christian) Adolescent girls and boys interviewed also acknowledged the overriding role of poverty as a factor driving them into sexual relationships with older men or women in their communities:

'At home they would give me money and send me to the mill to grind maize. Yet I needed that money for my personal things. So, I befriended the mill attendant, much older than me. We made a deal, where he would grind the maize "freely" in exchange for love. Meanwhile, I would pocket the cash meant for grinding the maize.'

Research has shown that in poor rural areas lack of access to education, health services, employment and a weak economy often push women and girls into age-disparate sex for potential economic gain. For example, Luke and Kurz (2002) in Bantebya et al (2014) elaborate how girls end up in relationships with men who can provide the money they need for school fees and other supplies. Money obtained is used to pay for education, buy food or clothes and luxuries such as soaps, body lotions, and snacks. Simple gifts such as a pencil or a packet of peanuts are sometimes enough to lure 
a girl into sex with an older person. In addition, Parental pressure to relate with an older working man is also a factor as a means of getting cash and household necessities and of marrying and fetching bride-wealth.

In urban areas material gain was found to be a leading factor luring young women to have sex with older men. Entertainment and fun emerged as major bases for such unions, with fun tied to glamour and enjoyment of material goods and lifestyle consistent with urban life. For young women whose parents provide the necessities of life, relating with older men was not about meeting subsistence needs, but about acquiring a 'top up' that helped boost their status in the eyes of peers and being known to society with well-to-do, rich-like people, renowned individuals in society. This was revealed by one 17-year-old involved with a 37 -year-old man:

"It's all about peer pressure, we compete with the type of cell phone we have, our hair styles, the type of vehicle our boyfriends drive, and the amount of money they give."

The fieldwork found that the engagement of adolescent girls in transactional sex with older men was not always driven by dire income poverty and meeting basic needs such as food, shelter or education. According to many of the adolescent girls and boys interviewed, transactional sex is rather driven by new 'needs' or an aspiration to achieve social mobility as a result of living in an urban environment with more external influences, peer pressure and expectations of access to material goods such as mobile phones, cosmetics, fashionable clothing and the ability to afford services like hair styling in salons, among others.

Although for extremely poor girls in the urban setting the initial engagement in transactional sex might be aimed at fulfilling basic needs, this transforms over time to include other material goods. This situation has resulted in a different way of viewing these adolescent girls, more as agents finding a means to achieve their ends than as girls who have limited opportunities and options in a context of peer pressure and external influences, which pressure them to engage in risky sexual relationships where they have limited control and are unable to negotiate their sexual and reproductive health through the use of condoms. This perception is reflected in the following quote by a young female peer educator working for a local NGO:

'Most girls go with sugar daddies because of greed for money. Their male age mates lack cash, and so play hit and run. With the sugar daddy you don't have to beg for money. He gives it readily so that you don't reject him. Then you can go to the salon and change your hair style, buy clothes and cosmetics, pay your school fees or adopt a trendy life style (swagger) and the other girls will envy you' (Small group discussion)

\section{Motives for engagement}

Evidence from the majority of participants indicates that cross-generational sexual relationships are common among adolescents, particularly girls, and that most of these have a transactional element. In both the rural and urban settings researched, the drivers of intergenerational sex were broadly similar, and included economic hardships characterized by acute income and subsistence poverty; discriminatory social and cultural norms; a high-risk physical environment; peer pressure; and inadequate care environments at home, characterized by, among other things, parental abuse and neglect. The following sections explore the drivers through findings captured during the fieldwork.

\section{Socio-cultural and religious drivers}

Culture and traditional practices also emerged as significant in the cause and perpetuation of intergenerational sexual relationships. In predominantly rural areas, where cultural norms and ethos still influence dominant thinking and the functioning of society, the determination of both girls' sexual maturity, age of sexual debut and marriage is still based mainly on bodily and physiological changes, which are characterized by the onset of puberty and not age per se.

'In this community a girl is seen as mature when she grows breasts and starts menstruating. For a boy once he breaks his voice or grows a beard, he is a man. Either of them think they are not bound by any Law in Zambia not to engage in any sexual relations with persons older than them, once they come of age. Yet, the Zambian Law prohibits sex with minors [Sec 138 of the Penal Code 
(Community Development Officer, Female aged 48; Community Development Officer, Male aged 45; District Education Standards Officer, Male, aged 51).

The Bemba speaking people are right when they use this proverb: "umwanakashi uwa ma bele, talangwa inshila" meaning that a female child who attains sexual awareness does not appreciate any advice or warning based on the fact that they too have breasts. As a result, these girls do not take advice no matter how much is said to them and no matter what they see their elderly ones undergo or face. The examples they see of other girls whose lives have come to a standstill, education opportunities lost, early marriages with early divorce and HIV/AIDS seem somewhat invisible to them. The girls think they are special sleeping with these older men of fame and are renowned in their communities, when in the actual sense the men just mess up their lives. Teachers interviewed observed the following:

As teachers, we now just look at these girls. They do not take our advice. Ministry of Education is partly to blame. The Education for All has its own bottlenecks. We are now enrolling big girls in grade one who already have had sex. They are ready for any offer in return for sex. They even offer themselves for sex flirting with teachers, and teasing that we are not men enough (Interview, teachers)

\section{Drivers based on family instability, sexual abuse and neglect}

Instability, abuse and child neglect, inside the family or household, were reportedly very common and to be driving children into intergenerational sex. The quotes below illustrate this:

'There are situations where the children are in the hands of stepmothers. There are situations where the girls are badly beaten and even chased away from home at night and unfortunately the only people who can accommodate them are the older men since they have houses or can afford to rent lodges which their male peers cannot' (Small group discussion A).

'Unfortunately some fathers, especially those who use drugs and alcohol, force their daughters into sex with them. Such girls get frustrated and run away from their fathers' home only to land in the hands of other men who use them for pay. The girls trust their fathers who betray them. Such an incestuous act begins with a seemingly innocent comment by the father such as, "My daughter you resemble your mother. In fact, it is okay to have sex with me as your mother does' (Small group discussion B).

'I got a man when my father died. I thought he was going to help me. He promised to marry me and when I became pregnant, he kept quiet. We stayed together for two months. When I became pregnant, he would give me many things. Even when the baby was like one month, he would provide but now he has changed.' (Interview, Girl aged 15)

'My story is long. I fist had sex with a big man when I was 13 years old. He ate my virginity. I was sent to buy eggs by mother in night because my father refused to eat the relish she had cooked. A midst their quarrel my mother asked me to rush out and get eggs to cut down the argument because he couldn't stop. Angry with my father for failure to understand my mother, I agreed. I went out running and crying only to bump into this man. I knew him as he lived in the area, he was very good and to protect me, he walked around with me looking for eggs. As we walked back home, he sweetly convinced me into having sex with him. He insisted that no one would know. That he would be gentle and that it was something all my friends were doing. He gave me some money and that was the beginning of a relationship. We had sex every week after that especially when my father returned from his drinking spree. I managed to escape from home to meet up with him as my mother's attention was all on my father. I now have two children with him but no one knows they are his. Now I have sex with many older men. The boys are inexperienced for me.' (Interview, Girl aged 17)

'I am a product of an intergenerational relationship. My mother was chased from home when she got pregnant with me. She left home and to support me she continued her sexual activities to bring me up because, my so-called father refused claiming she was trying to break his so-called stable marriage. I grew up in a home where different older men came in and out. That is where my story begins. My first sexual experience was when I was 12 years old with one of my mother's usual's. She [my mother] was not home and I decided to help her [she smiles]. That man almost shuttered my vagina. I have never seen such a package [the penis, she emphasizes]. When my mother learnt, because I was 
limping around with pain, she chased me from home. Now am 15 years old living on my own and older men keep me by providing me money in exchange for sex.' (Interview, Girl aged 15)

'I am in grade 11 and I pay my tuition fees from my encounters with older men. I use contraceptives to protect myself from falling pregnant am sure you will ask. Older men pay very well. I started having sex with my teacher in grade 8 . He convinced me as a means to help me through school. I didn't want but I started. I think he told his friend because I started getting offers from more teachers. They don't pay me but I know they help me pass. I am now in grade 11 and I know I will pass my grade 12. If I want sex for money, I go to the lodges where expatriates working in the mines pay very well. My mother and father divorced when I was in grade 8. My mother knows what I do but she is not bothered because I am helping her too' (Interview, Girl aged 17).

\section{Peer pressure and lifestyle choices}

In addition to economic and sociocultural drivers, youths identified peer group pressure as an emerging push factor of both girls and boys into intergenerational sex. Adolescent girls and boys explained that girls, but also some boys, engaged in relationships with older men (or women) even if their basic needs were met, as it was seen as way to gain access to 'luxury' goods they would not otherwise have, but for which there is social pressure among peers to obtain - from perfumes to clothing articles. In fact, some respondents mentioned that even those coming from stable well-to-do families were known to engage in cross-generational sexual relationships with older men for various reasons, including sexual gratification and acquisition of luxury items such as smart phones and plasma screen TV sets:

'Some girls are blessed with everything but still go with the old men. They are influenced by their peers who are doing it. Now it has become a trend, even girls from well-to-do families are going out with old men, fit to be their father'. (Guidance and Counselling Teacher, Male, aged 47; Community Development Officer, Male aged 45; Education Standards Officer, Female, aged 50)

The narration from the girl below is proof of what the Guidance and counselling Teacher claims. The girl does not need the money at all but engages in the cross generation sexual relationship because of peer pressure.

'I come from a good family. I have everything. My father gives me money when I ask him but you, sex is a hot topic among my friends. I had to try because I didn't want to be the only one out. So, my friends took me to the shanty compounds, Wisdom, where there are rooms that these older men hire. These are important, well placed married men who do not even live in the slums but go there for sex only. They don't want to be known. They pay very well, I should say although I can still say, I do not need the money I get' (Interview, Girl aged 16).

'Many others who fall in sexual relationships with older people are not needy, they see it as a trendy life style' (Small group discussion B)

This focus group discussion revelation collaborates with what the Community Development Officers, District Education Standards Officer and Parent Teacher Association unanimously observed too.

This is a 'touch and go' generation. Technology has brought so much good and bad at the same time. There are so many beautiful things which are just there waiting for you to make a move and it looks like everyone is managing to get these things. Many girls are falling into great temptations. Their families are unable to provide for. These are just wants; latest phones, handbags, human hair, powders.

The sentiments of the church are true of the example of the girl below.

Look around yourself. Anywhere, in the bus, at school, in church, in town etc. everyone looks like they have the money to buy anything. I could not refuse the offer of money to buy human hair from an admirer in the bus. I sat with this man who lavished me with praises of my beauty. He then suggested that if I braided with human hair and change the makeup I was wearing, my beauty would be turning every boy and man towards me. I was flattered but I agreed. Payment was just sex for one night with him. So, I rung my mother that I was staying at my cousin's that night to do my hair. I spent a night with this man and he paid me well. I now do it for anything I want and I tell my parents a lot of lies to 
prove where I get these things. I am sure it's not me alone who is doing these things. Do you think all these girls with latest things are given by their parents? (Interview, Girl aged 14).

Girls are not difficult to get into bed. I have done it a number of times. Just offer them these latest things, they are ready to offer you sex. Now I buy mobile phones to give away. So, I will have three smart phones ringing on me and then I just offer one out to this unsuspecting girl with no phone. You should see the excitement! (Interview, Male aged 55).

\section{Sexual gratification}

The proliferation of pornography, especially 'blue films', was affirmed as a reality in communities. Makeshift video halls where pornography is shown are reportedly abundant in communities. It was also noted that old men and women show blue films in their homes to lure girls and boys, respectively, into illicit sex. Male youth said girls deliberately opted to have sex with old men to explore the myth or perception of heightened erotic virility and pleasure often associated with having sex with old men but described as lacking in boys.

'The penetration of an old man is deep, not attainable or comparable with that of a boy' (Small group discussion $C$ ).

This perception was echoed by most of the sexually active out-of-school adolescent girls. They agreed that their male peers compared poorly with old men when it came to matters of sexual intimacy.

I told you earlier that, the first older man I had sex with had a big penis. Woooo, when I tried with a boy, I mean a boy he literally swam inside me. It was like sex with a fellow woman. You need to feel a man inside you. So, for me I go for older men (Interview, Girl aged 15).

Young girls are intact. You squeeze yourself in and the heat and the sensation are unforgettable. You want more and more and all you do is run away from your wife to experience this again and again (Interview, Male aged 61).

It's a shame really that an old man can expose himself to a girl the same age or even younger than your own daughter. I am even ashamed to talk to you about this. I have to stop. These girls watch so many things on their phones and they do anything. My wife will never accept giving me a blow job but these girls will do it. That is all I do so I don't get them pregnant. I pay so much money than those that go all the way but I think I get the most satisfaction (Interview, Male aged 66).

\section{Restricted access to community resources and essential services}

Restricted or lack of access to community resources such as wells/bore holes and essential services such as health care, education, water and sanitation, child protection and other welfare facilities can combine to complicate and deepen the various risks and vulnerabilities girls and boys are exposed to in terms of cross-generational sex. For example, the physical distance to facilities, particularly wells, bore holes, mills and even schools, means adolescent girls can be exposed to sexual abuse by men on their way. When distances are particularly long, places are difficult to access or loads are difficult to carry, girls may be compelled to seek the assistance of older men, with the promise of reciprocating with sexual favours. Taxi drivers are regarded as frequent victimisers, luring girls into sex in exchange for 'free' rides to school. But not all girls hold this view, as evident by the narrative by 10 girls (whose age range is between 16 and 21) interviewed captured below:

I have no trust in older men. There is no help that they will give you without seeking for favour. I can give you a lot of examples of men I have had sex with [she lifts her right hand and begin to count using her fingers, she started pointing at the first figure... one:

1. A policeman who said he can escort me home because it was late demanded sex off me as payment.

2. A village elder, who claimed he would give me free land if I had sex with him.

3. A bus driver, who allowed me not to pay for the ride but instead demanded sex.

4. The head teacher who instead demanded sex from me in exchange for the punishment for the offence I committed.

5. My father's friend, who saw me with another older man and so he cannot report me to my father, I pay every time with sex on demand. 
6. It's a long list. I do it now for anything. I move with condoms in my bag [she broke down], I don't know if I will ever get married because I think men know me now (she continued, sobbing until the interview was stopped].

\section{Challenges}

The consequences experienced and/or perceived by adolescent girls and boys involved in crossgenerational sex or regarding its occurrence can be categorized into positive (leading to improved economic wellbeing) and negative (causing or exacerbating ill being). The analysis below notes when they described consequences that are the result of experiences of adolescent boys and girls involved in these types of relationships or of perceptions by others, either adolescents or adults in the community.

Negative consequences were widely identified, both by those who had experienced crossgenerational sex and by others in the community identified for this study. Bantebya et al., (2014) has explained such consequences for the girls who indulge in cross-generational sex. The girl above is an example of negative consequences of intergenerational sexual relationships. The girl is traumatized and has lost trust in older men who have sexually abused her. It's clear that this girl has now become vulnerable to some older men.

I have aborted five pregnancies. I do not regret because I would not have reached grade 12. I know a woman in the village who uses traditional medicines and I go to her to help terminate the pregnancies (Interview Girl aged 18).

I first gave birth from an older man when I was 14 years old. Since, I have never healed. The hospital says I have fistula, a condition that occurs when a young girl gives birth at a young age. I leak so I wear pads every time (Interview Girl aged 19).

Unanimously, respondents in the Health sector revealed that Fistula is a health complication occurring in young adolescents today, prevalently. The Policy Brief on the Status of Sexual and Reproductive Health and Rights in Zambia (2017) attest to this. The brief explains that teenage girls who fall pregnant tend to drop out of school, enter into early marriages and have a proclivity to teenage pregnancy health complications that include fistula and unsafe abortion.

Some of the negative consequences, lived and perceived, included heightened vulnerability to infection with HIV/AIDs and other STDs, which female respondents associated with old men, who tend to be more sexually active and to have had multiple partners; increased vulnerability to unwanted and risky early pregnancies; unsafe abortion and the associated higher risk of maternal morbidity; and injury or trauma of the reproductive system when young, physiologically immature and sexually inexperienced girls are initiated into penetrative sexual intercourse with older and sexually experienced men. Most of these sexual and reproductive risks are attributed to the inability of young, naive and timid girls to demand or negotiate safe sex.

Compared to those respondents in urban, positive consequences mentioned by respondents focused on adolescents having more immediate material concerns, such as money in the short term either to pay for basic needs or, more commonly, to pay for goods they could not otherwise afford. These respondents nevertheless reported the same protective and security concerns as those in the urban environment.

It was reiterated that, despite their high prevalence and trivialisation, cross-generational sex rarely offers tangible and sustainable benefits for the adolescent girls involved. Girls who are abandoned while pregnant or soon after birthing do not only drop out of school but also suffer considerable psychological trauma associated with the pain of rejection not only by their male partners but sometimes by their natal families as well. As a result, these girls suffer a loss in self-confidence and self-worth. Many, after engaging in one transactional sexual relationship with an older man, start to do this more frequently.

In contrast with the above, some adolescent girls who had engaged in transactional sex with older men had become pregnant and were now adolescent mothers, and blamed their situation on economic hardship and ill being, as they felt these rendered transactional sex their only option for survival, even when it carried the risk of STDs and sometimes violence. Although they described the old men who prey on young girls derogatorily, at the same time they expressed their preference for cross- 
generational sex owing it is assured financial and material advantages compared with sex with their peers.

More often than not these girls become destitute, with no place of abode. Some adolescent girls with young children mentioned feeling that their children, particularly girls, would also have to sleep with older men when they got older to survive, particularly as it was what they had witnessed from a young age.

In addition, many interviewees mentioned abuse and physical violence as being common in these relationships. According to the participants, this results from girls trying to negotiate use of contraception; sometimes it is just because some men are violent and feel entitled to be violent with the girls they are with. Meanwhile, the guidance and counselling teachers, community development officers and social welfare officers revealed that there is an increase in the number of young men engaging in intergenerational sexual relations, many are also beaten by the older women and ladies they are involved with or married. Violence comes in because the women feel they are providing all the young men want and need (shelter, car, money and food) and are over-protective, always thinking that the young men quote or have extra-sexual relations with ladies of their age range.

Furthermore, participants disclosed that given that cross-generational relationships can result in marriage or cohabitation, other negative consequences identified included increased proneness to premature widowhood as a result of pronounced inter-spouse age differences; insecurity in the matrimonial home owing to potential eviction by hostile in-laws on the demise of the husband; vulnerability to physical abuse or disrespect by grown-up children who deliberately refuse to recognize a girl's new and heightened stepmother status; poor health and premature ageing associated with prolific child bearing, owing to old men's desire and demand for many children; living with the social stigma that marriage to a man of advanced age attracts; and above all abandonment while pregnant as a result of back tracking by the male partner/husband on his earlier promise of marrying the girl and providing her with social security.

However, studies have shown that risk perception by both partners is often low. Young women may view the older man as a safer sexual partner; the older man is often perceived as less risk taking, more stable, and more responsible (Leclerc Madlala, 2008).

But it is not just money. Of special concern is the risk of contracting HIV and AIDS in agedisparate partnerships. While young women associate ability to attract and exploit older partners with modern freedoms linked to gender equality, and while securing and maintaining relationships with older, employed men is considered 'clever' and an important contribution to young women's selfperception as sexually-liberated, the strategy exposes them to HIV (Shefer, Clowes, \& Vergnani, 2012; Jungar and Olinas 2004; Patton 1990; Seidel 1993).

\section{Benefits}

Women see many benefits in having older 'sugar daddy' boyfriends. Some aim for marriage, with older men seen as more serious and better potential marriage partners than same-age partners. Across southern Africa, girls are encouraged to seek older men as partners and husbands. Families caution against marrying a man of similar age as this is believed to increase the risk of marital instability.

Some who wish to avoid marriage still aim for economic independence with older men seen as a means to achieve this goal. With the men's help, they can further their education, secure better jobs, build capital, or gain social mobility.

Some young women claim that older men are better at and more interested in satisfying them sexually. Their need for love, affection, and affirmation has been stressed in some studies as important but it often overlooked the young women's motives for going with older men. As a young woman attending one of the region's tertiary institutions put it:

'Older men are nicer than the young ones. They listen, they are patient and tender. You can see they appreciate you more.'

There is prestige in dating a man who is a well-known or respected public figure. To be seen riding in an expensive automobile, or dressed in trendy clothing, or with a top-of-the-range cell phone are viewed as status-enhancing by young women in the region. 
From this social benefit comes a personal benefit, the boosting of self-esteem and self-confidence that some studies have reported as especially important for young women. Their ability to improve young women's status, including social mobility, has earned older men tags such as 'sponsors' 'investors' or 'ministers'. The concept of the 'Three C Girls' (young women who sexually exploit men for cash, cars and cell phones) is well known across the entire southern Africa region.

Studies also tell us that notions of manhood are closely tied to a man's ability to attract and maintain sexual partners. The need for entertainment, variety and relief from domestic and workplace stress are considered as some of the drivers of men's sexual involvement with younger women. A desire for 'clean partners' perceived to be free of STI or HIV infection is reportedly a major reason for men going for young women.

Myths that HIV can be cured through sex with a virgin or that an older man can be sexually revived by sleeping with a younger woman are common excuses for intergenerational sexuality. In some communities an ageing man is entitled to a young woman to 'make his blood move again', and often his ageing wife has to find the young woman to 'service' her husband.

Literature on transactional sex, in sub Saharan Africa, has often separated drivers of the practice into sex for consumption and sex for subsistence (Hunter, 2002; Zembe et al, 2013). Although young women were often placed in the context of poverty, all respondents in this study believed that young women most frequently pursued transactional sex for goods of consumption, such as fashionable clothing, cell phones, drugs, and alcohol. Often times, the young women reported that the older man simply provided money; the women then would use the funds to purchase these material goods.

While sex for consumption was more commonly referenced, all the young women cited the use of transactional sex for subsistence needs. The exact parameters of sex for subsistence have been difficult to locate in past literature, but general goods of subsistence or "needs" have been defined as food, essential clothing, and school fees in past studies (Leclerc Madlala, 2004).

School fees, food, and employment were commonly cited as the needs of young women coming from poor families. Alternative Motives for Transactional Sex: Fun, Love, Preference, and the Silence of Sexual Pleasure: Fun was the most commonly cited alternative motivator for young women to engage in intergenerational, transactional sex. Nearly half of the interviewees considered it a significant reason for their peers to pursue sugar daddies. The pursuit of love and marriage was vehemently denied as a component of transactional sex by some young women; others believed that it could occasionally become a factor.

\section{Critical reflection}

There was no unanimity on important definitions such as girlhood, adolescence and adulthood/womanhood and related issues such as age of sexual consent and marriage. As such, crossgenerational easily becomes normalised, as adolescent girls who are seen as 'sexually mature' are perceived as being available for sex, even if legally the age of consent is 18. In fact, most relationships including cohabitation and marriage in the community involve girls or women with much older male partners.

Cross-generational sex is thus not perceived as a child protection violation, but as a normal and socially acceptable phenomenon, not attracting punitive social sanctions. A girl or boy's physiological maturity, characterised by distinct bodily changes, takes precedence over numerical age in the definition of adulthood.

Discussions with adults and adolescents alike indicated that, although girls' and boys' involvement with old men and women, respectively, was attributed largely to naivety coupled with poverty, some of the boys and girls were actually not materially needy but only psychosocially vulnerable.

Peer pressure is expressed more in terms of the social acceptability of cross-generational sex and the pressure to form relationships from a young age, as discussed earlier, particularly for girls. However, adolescent girls interviewed in small group discussions also noted that it was not uncommon for adolescent girls attending school (who are thus not among the poorest) to desire things their parents cannot afford. This drives them into going with older men who have money, particularly as they see friends with 'nice things' and want to have them too. 
The relationship between intergenerational sex and higher risk of HIV infection has recently been called into question. As suggested above, previous cross-sectional studies of HIV prevalence have indicated that younger women in cross generational relationships are placed at a higher risk of HIV infection.

Drivers of transactional sex are varied and complex; alternative motives for young women include the pursuit of fun, potential love, and partner preference. Sexual pleasure was utterly absent from discussions regarding transactional sex by the young women in this study, reflecting the country's roots of patriarchal society and dominant discourses surrounding gender and sexuality. Young women are often active agents in transactional sexual relationships, and cannot be regarded as passive, exploited victims. This study cites several cases of young women purposefully pursuing, initiating relationships, and exploiting their older male partners. Females challenge gendered economic inequalities by utilizing their sexuality for access to economic power and resources traditionally held by men. Both men and women maintain multiple concurrent partnerships amongst practices of transactional sex.

Female agency in transactional sex serves to both disrupt and reproduce patriarchal norms. The power dynamics between older men and young women in transactional sexual relationships have crucial implications for high risk sexual behaviors.

This study found that socioeconomic status likely exacerbated gender inequalities within a transactional relationship, leading to gender-based violence. While transactional sex can prove to be socially, psychologically, and financially beneficial and meaningful for both parties involved, it seems to be deemed as a scorned, immoral pathway to success in the eyes of young women who do not partake in such relationships.

The young women of this study are well aware of the health risks of transactional, intergenerational sexual relationships, such as HIV infection and pregnancy. This knowledge, however, does not drive their decision to abstain from sugar daddy relationships.

Overall, what remains unclear is the extent to which the boys and girls who get involved in crossgenerational sex with older partners see the damaging negatives before engaging in these relationships, or whether they realise the damage only once they have experienced it.

Given the social acceptance or frequency of these relationships, it can be hypothesised that many young adolescents think only of the very limited positive consequences of these relationships, without actually weighing the long-term negative costs. For others, given their limited options, they might still see it is as the only alternative, even when they are aware of the risks.

\section{Conclusion}

This study provides evidence on the high incidence of cross-generational sexual relationships in the research sites visited. Acute income poverty and its stultifying effects, subjecting both boys and girls to a myriad of vulnerabilities, are identified as a key push factor for cross-generational sexual relationships. Sociocultural and other challenges, such as peer pressure, discriminatory social norms, lack of and poor-quality services and dysfunctional families also emerge as significant drivers.

Drivers of transactional sex are varied and complex; alternative motives for young women include the pursuit of fun, potential love, and partner preference. Sexual pleasure was utterly absent from discussions regarding transactional sex by the young women in this study, reflecting the country's roots of patriarchal society and dominant discourses surrounding gender and sexuality.

This study found that socioeconomic status likely exacerbated gender inequalities within a transactional relationship, leading to gender - based violence. Furthermore, the consequences adolescents experience as a result of engaging in cross-generational relationships are common across rural and urban contexts. Some of the adverse effects include sexual abuse and exploitation, physical abuse, early marriage, unwanted pregnancy, single motherhood, exposure to HIV/AIDS and other STDs and psycho-emotional trauma. These consequences usually overlap, resulting in adolescents being unable to access their rights. 
ISSN: $2520-3088$

\section{Recommendations}

A number of factors were found to play a critical role in pushing of trans generational sex which policy makers would do well to look at and are citied as follows:

1. Poverty is a major factor given as the reason why adolescents both male and female would get involved into this act. It is important therefore that the people are equipped with necessary tools that will enable them to find alternatives to replace the use of engaging into sex with older men and women as a means of survival.

2. Education and awareness must be enhanced in communities similar to the settings in which this study was conducted in especially on issues pertaining to the implications of trans generation sex so that the young people are made aware of the long-term effects than simply focusing on the short lived economic value harvested in the short term.

3. Trans-generation Sex in the case of this study was a result of the economic boom coupled with cultural and social beliefs/practices of the local people, it is important therefore that policy be generated to the effect that whenever such situations are foreseen mandatory sensitization should be undertaken by investing companies to avert the social backlash that would arise.

4. More studies need to be conducted to have a thorough understanding of underlying factors and motivating reasons for young people to focus more on short term benefits even in the face of knowing the serious results of such activities. This is so that the social ramification of the practice has downturn effects on the overall development of a nation.

\section{References}

[1]. Adogu, P., Udigwe, I., Udigwe, G. and Ubajaka, C. 2014. Review of Problems of Adolescent Sexual Behaviour and the Role of Millenium Development Goals 4, 5 and 6 in Nigeria. International Journal of Clinical Medicine, 5(8), 9.

[2]. Bales, S.S., Eklund, S.J., and Siffin, C.F. 2000. Children's perceptions of elders before and after a schoolbased intergenerational program. Educational Gerontology, 26, 677-689.

[3]. Bantebya. G., Ochen, E., Pereznieto. P., and Walker, D. 2017. Cross-generational and transactional sextual relations in Uganda: Income poverty as a risk factor for adolescents.

[4]. Bennett, R. 1976. Attitudes of the young toward the old: A review of research. Personnel and Guidance Journal, 55, 136-139.

[5]. Berk, L.E. (ed.) 2003. Child development. (Boston: A \& B).

[6]. Blunk, E.M. and Williams, S.W. 1997. The effects of curriculum on preschool children's perceptions of the elderly. Educational Gerontology, 23, 233-241.

[7]. Bronfenbrenner, U. 1987. Nobody home: The erosion of the American family. Psychology Today, 10, 4047.

[8]. Erikson, E.H., Erikson, J.M. and Kivnick, H.Q. 1986. Vital involvement in old age. (New York: Norton \& Co. Inc.)

[9]. Hickey, L.A., Hickey, T. and Tallish, R.A. 1968. Young people's perceptions of the elderly. Journal of Genetic Psychology, 112, 227-235.

[10]. Ingoldsby, B.B., Smith, S.R. and Miller, J.E. (2004). Exploring family theories. (Los Angeles: Roxbury).

[11]. Issacs, L.W. and Bearison, D.J. 1986. The development of children's prejudices against the aged. International Journal of Aging and Human Development, 23, 175-194.

[12]. Leclerc-Madlala. S. 2008. Age-disparate and intergenerational sex in Southern African: the dynamics of hyper-vulnerability. UNAIDS, 22(4)

[13]. Mavhandu-Mudzusi. A.H. 2014. Factors Contributing to Intergenerational Sexual Relationships among Refugee Girls in the City of Tshwane: South Africa Mediterranean. Journal of Social Sciences MCSER Publishing, Rome-Italy, 5, 20

[14]. Miller, S.M., Blaloc, J. and Ginsberg, H. J. (1985). Children and the ages: Attitude, contact and discriminative ability. International Journal of Ageing and Human Development, 19, 47-53.

[15]. Rubin, G.S. 1993. Thinking Sex: Notes for a Radical Theory of the Politics of Sexuality. In Abelove, H. (ed). New York: Routledge. 